\title{
"Antysocjalistyczne pogaduchy". O narracyjnych polilogach lokomocyjnych
}

Dorota Samborska-Kukuć

TEKSTY DRUGIE 2019, NR 3, S. 115-125

DOI: $10.18318 /$ td.2019.3.7 | ORCID: 0000-0002-1943-6694

Istnieć - to znaczy dialogowo obcować z kimś.

Michaił Bachtin

Dialog to budowanie wzajemności.

Samotność życia zostaje [...] na moment

Józef Tischner

rozjaśniona przez wspólne światło dyskursu

Paul Ricœur

$\mathbf{P}$ odróżowanie publicznym środkiem transportu stanowi specyficzną formę obcowania człowieka z człowiekiem. Niewykluczone, że intensyfikuje się wówczas wskutek powstania zamkniętej przestrzeni a w niej swoistego układu inercjalnego - szczególny rodzaj interakcji: międzyludzka solidarność (skazanie na siebie). Sprzyja ona nawiązaniu dialogu. O nie tylko fatycznej funkcji werbalnej współpasażerów („rozmowy kontaktowe” np.o pogodzie) mogą decydować determinanty osobowościowe (potrzeba

\section{Dorota}

Samborska-Kukuć prof. dr hab., kieruje Zakładem Literatury Pozytywizmu i Młodej Polski w Uniwersytecie Łódzkim; jest historykiem literatury; ostatnio opublikowała książkę Twarze Draculi i inne pre-teksty metafizyczne (2018). Kontakt: ddsk@wp.pl

1 Stałe pojęcie w pracach naukowych dotyczących typologii illokucji, zob. m.in. U. Żydek-Bednarczuk Struktura tekstu rozmowy potocznej, Wydawnictwo UŚ, Katowice 1994, s. 150. 


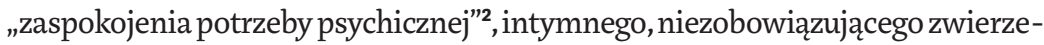
nia się komuś obcemu), temperament, czynnik temporalny wyznaczający czas przebywania w drodze, ale także bodźce zewnętrzne. Do tych drugich należą inspiracje zainicjowane artefaktem wzbudzającym ogólne zainteresowanie aprobatę bądź sprzeciw, wywołującym wymianę zdań na tematy uniwersalne typu „co tam, panie w polityce?”; ich transgresje mogą prowadzić do sporów między antagonistami, do wymiany inwektyw, a nawet - przy odpowiednich warunkach, tj. ekspresji interlokutorów i dynamice konwersacji agitato - do rękoczynów jako radykalniejszej niż słowa metody perswazyjnej.

\section{** *}

W celu wskazania specyfiki konstrukcyjnej i dramaturgii lokomocyjnych dialogów pluralistycznych, czyli prościej - polilogów ${ }^{3}$ dotyczących kwestii politycznych, posłużę się wyrazistymi przykładami wyjętymi z dwu powieści ${ }^{4}$ tworzących niejako tę samą „wspólnotę komunikacyjną"5. Pierwszy z nich to fragment Madame (1998) Antoniego Libery, powieści rozwojowej, zbliżonej do Künstlerroman, portretującej „artystę z czasów młodości”, drugi jest wyimkiem z mniej ambitnej, należącej do literatury popularnej, Ręcznej roboty (2010) Ryszarda Ćwirleja, reprezentującej kryminał neomilicyjny. Niemal paralelne strukturalnie ${ }^{6}$, zbliżone tematycznie, o podobnym, żywym przebiegu

2 Tamże, s. 151.

3 Terminu "polilog" używam w znaczeniu najprostszym jako dialog (a więc komunikat o tej samej strukturze) więcej niż dwu osób; wielogłos. Pojęcie to ma kilka odmian znaczeniowych, np. Julia Kristeva (Polylogue z roku 1977) używa go w odniesieniu do komunikacji transkulturowej.

4 Polilogi - nie tylko lokomocyjne, ale charakterystyczne dla wszelkich zgromadzeń, zbiegowisk etc. uobecniają się w wielu tekstach narracyjnych (od Próchna począwszy), nierzadko są teatralizacyjne i stanowią reprezentacje wielogłosowości uczestników jako wariacji nie tylko światopoglądowych, ale i różnorodności tożsamościowych wyrażanych w wielopoziomowych - werbalnych i pozawerbalnych, konstrukcjach wypowiedzi. Warte uwagi są zwłaszcza polilogi w Złym L. Tyrmanda czy Urodzie na czasie L. Buczkowskiego.

5 Pojęcie „wspólnoty komunikacyjnej” jako „zgodne reagowanie podobnych ludzi na te same (podobne) wydarzenia i jest efektem przeżycia otoczenia dłużej trwających w czasie sekwencji zdarzeń" definiuje A. Skudrzykowa Język (za)pisany, Wydawnictwo UŚ, Katowice 1994, s. 17.

6 W obu powieściach polilogi te mają charakter komentowanego przytoczenia, stanowią przykład tzw. czyhania narratora na słowa postaci; o tej kwestii pisał W. Bolecki Poetycki model prozy w dwudziestoleciu międzywojennym. Witkacy, Gombrowicz, Schulz i inni. Studium z poetyki historycznej, Universitas, Kraków 1996, s. 141. 
i nasycone osobliwym humorem (słownym i sytuacyjnym), są literackimi egzemplifikacjami vox populi. Jednocześnie stanowią krotochwilną, lecz bynajmniej nie dezawuującą ilustrację teorii dialogu księdza Józefa Tischnera, jego chrześcijańskiego (personalistycznego) „braterstwa dla porażonych", wszak pokazują ludzi kolektywnie protestujących przeciw ograniczeniu wolności obywatelskiej przez socjalistyczne instytucje opresyjno-represyjne.

\section{Realia i temporalia}

Obaj pisarze, osadzając czas akcji w okresie PRL-u (Libera w połowie lat 6o. w Warszawie epoki Gomułkowskiej, Ćwirlej dwadzieścia lat później w Poznaniu), eksplorują patologie i absurdy tamtej epoki, począwszy od opisu dookolności: szarej, ponurej, brudnej, noszącej znamiona inspiracji sowieckiej zarówno w kształcie architektonicznym, jak i w schludności. W ten monochromatyczny pejzaż zostają wmontowane sceny dialogowe, które rozgrywać się będą w obskurnych pojazdach komunikacji miejskiej, a ich uczestnikiem - mimowolnym - będzie powieściowy protagonista. I choć obu bohaterów różni niemal wszystko, pierwszym jest bowiem pochodzący z inteligenckiego domu maturzysta o liberalnych poglądach (porte parole Libery), drugim zaś prymitywny funkcjonariusz MO - Teofil Olkiewicz, znajdą się w podobnych sytuacjach, wymuszających na nich określone zachowania.

Młodego warszawiaka z przystanku KC przy Alejach Jerozolimskich zabiera pustawy autobus linii 117, by zawieźć go na „wysepkę Zachodu”, tj. do Ambasady Republiki Francuskiej. Nieumundurowanego natenczas milicjanta, śpieszącego się rano do pracy, z poznańskiej ulicy Feliksa Dzierżyńskiego uwozi ku komendzie zatłoczony zielony tramwaj nr 14. Co znamienne, i autobus, i tramwaj przekraczają mosty, symbolicznie niejako ewokując skojarzenia ze strefą graniczną, sygnalizując egzystencjalne przejście na drugą stronę.

\section{Czynnik inicjujący}

Mitręgę podróży na wpół wypełnionej kontemplacją „szarawych widoków”, tudzież rozważaniami bieżących spraw służbowych przerywają zdarzenia-katalizatory, których specyfika angażuje pasażerów i jak za dotknięciem czarodziejskiej różdżki inauguruje polifoniczną, kaskadową wymianę zdań $\mathrm{w}$ tonacji crescendo.

7 J. Tischner Etyka solidarności, Pryzmat, Warszawa 1989, s. 13. 
W Madame jest to wejście kontrolerów, potocznie zwanych kanarami, wzbudzających powszechną niechęć już to z racji opresyjności działań, już to ordynarności i demonstracji wyższości. Będąc jednym z organów wykonawczych znienawidzonej władzy, a przy tym wyróżniając się topornym emploi i brutalnym prymitywizmem, u jednych wywołują lęk i pokorę, u innych wręcz przeciwnie - pogardę i gniew. Libera odnotowuje te reakcje, traktując bileterów (stojących w rozkroku nad pasażerami) jako czynnik aktywizujący zbiorową abominację; bunt przeciw nim staje się jedyną godną postawą warszawiaka, Polaka, człowieka. Narrator-bohater właściwie nie bierze czynnego udziału w wypadkach, ale świadkując im, snuje refleksje nad niegodziwością Miejskiego Zakładu Komunikacji egzekwującego opłaty za przejazdy w rzadko punktualnych wozach, w dodatku wątpliwej czystości, dokonuje namysłu nad istotą socjalizmu jako utopijnej wspólnoty, nad zniewoleniem jednostki ludzkiej przez biowładzę w osobach brutalnych kontrolerów gotowych na przemoc fizyczną, na poszturchiwanie, potrząsanie, a nawet wzięcie pod ręce i wywleczenie z pojazdu, by na przystanku dopełnić formalności - bynajmniej nie tylko papierkowych. Solilokwium to zdradza umysł analityczny i zmysł krytyczny narratora, świadomego właściwego wymiaru zdarzeń i ich kontekstów społeczno-politycznych.

Inaczej rzecz się ma w Ręcznej robocie. Kontaminacja chaotycznych deliberacji Olkiewicza nad prowadzonym przez siebie śledztwem, którego trop prowadzi na Wschód, oraz nagłe spostrzeżenie gazika wojskowego z żołnierzami radzieckimi rozdrażnia milicjanta do tego stopnia, że wypowiada na głos konkluzję tych sekretnych medytacji: „Cholerne bolszewiki, szlag by ich wszystkich trafił!”. Ku własnemu zdumieniu i co gorsza, przerażeniu niefrasobliwością, to magiczne zdanie puszcza w ruch prawdziwą lawinę aprobatywnych komentarzy współpasażerów, sytuujących głupawego (i jeszcze po nocnej biesiadzie odrobinę nietrzeźwego) funkcjonariusza MO w centrum zdarzeń i nieledwie czyniących go herosem, a może i przywódcą dopiero co zawiązanej wspólnoty. Wystarczyły dwa przypadkowe zdania, by uruchomić nasze polskie zapotrzebowanie na bohaterstwo: „zaczęły wyciągać się zewsząd ludzkie ręce. Wszyscy chcieli choć dotknąć czy poklepać tego, który odważył się wystąpić przeciw ruskim"9. Teraz wystarczyłoby już - jak w powiastce Jerzego Kosińskiego - być! Najpewniej więc Nikodemem Dyzmą.

8 R. Ćwirlej Ręczna robota, W.A.B, Warszawa 2010, s. 188.

9 Tamże, s. 190. 


\section{Dramatis personae}

Reakcja zbiorowości w obydwu tekstach jest podobna. W powieści Libery odzywa się, siedzący dotąd cicho (tj. do chwili, gdy zaczyna się pyskówka między jednym z podróżujących, a kontrolerem) "chór wzburzonych obywateli",,stając murem" w obronie indagowanego. W Ręcznej robocie uczestnictwo błyskawicznie sformowanej wokół Olkiewicza grupy jednomyślnych staje się jeszcze wyrazistsze:

Nagle wokół Teofila zrobiło się jakoś dziwnie tłoczno. Początkowa cicha wymiana zdań stała się niepokojąco głośna i krzykliwa. Co rusz z głębi wagonu, to z jednej, to z drugiej strony dochodziły głosy aprobaty i sprzeciwu albo nawet aprobaty dla sprzeciwu. ${ }^{10}$

Oczywistą, wynikającą z przygodnego przecież uczestnictwa nieidentyfikowalność tożsamości uczestników polilogu lokomocyjnego wykorzystują pisarze w celu nadania im metonimicznych przydomków. W Madame są one wyszukane, godne erudyty, którym jest przecież narrator, w powieści Ćwirleja mniej subtelne, inspirowane wyglądem postaci tak, jak je widzi Olkiewicz. Czynnik inicjujący - kontrola podróżnych przez bileterów oraz nieopatrzna kwestia Olkiewicza - nie pozostają bez echa, ba, są jak magiczne znaki, które ożywiają bezbarwne, bierne figury statystów. Udział w polilogu w sposób naturalny formuje grupę „bojówkarzy”.W Madame z weteranem-koryfeuszem jako werbalną siłą przewodnią, w powieści Ćwirleja z fuzją głosów unisono tworzącą właściwie wypowiedź homofoniczną".

W starciu z antypatycznymi rewidentami uczestniczą czynnie, prócz innych „wzburzonych obywateli”, przede wszystkim dwaj starsi panowie: właściciel piecyka, którego postawiono w sytuacji upokarzającej, nie pozwalając mu, poprzez blokadę kasownika, przedziurkować biletu za bagaż, oraz „inwalida - starszy, barczysty mężczyzna o sztywnej prawej nodze - siedzący na miejscu dla kalek"12 i nazwany z uwagi na fizyczną ułomność asocjującą patriotyczne konteksty Sowińskim-w-okopach-Woli lub, krótko - jenerałem. Oni to wysuwają się na pierwszy plan rozgrywających się - nieledwie krwawych - wypadków autobusowych.

10 Tamże, s. 189.

11 W rozumieniu Bachtinowskim jako wypowiedź jednogłosową.

12 A. Libera Madame, Znak, Kraków 1998, s. 228. 
Organizujący tramwajowe braterstwo słowa „lekkomyślny” komentarz Olkiewicza porusza patriotyczne sumienia współpasażerów. Do pomstowania na „ruskich” oraz wszystkiego, co kojarzy się z Krajem Rad, socjalizmem, PZPR-em, a także - ku zgrozie Olkiewicza - z Milicją Obywatelską („milicyjne ścierwa”) włącza się spora grupa podróżujących poznaniaków. Poza dwiema rezonującymi kobietami, z których jedną nazywa się „moherową", a drugą „szczuplejszą, ale znacznie głośniejszą”, a także „długowłosymi studentami”, „zarośniętym” pijakiem wybudzonym „ze snu sprawiedliwego” i „pryszczatym czternastolatkiem”, jest i weteran, „drobny staruszek” odwołujący się w ripostach do narodowych tradycji orężnych.

\section{Bój}

Kolokwia lokomocyjne Libery i Ćwirleja, choć wskutek mistrzowskich zabiegów retorycznych budzące czytelniczą wesołość, są w istocie nie tylko wynikającymi z rozhuśtania emocji pyskówkami ad personam czy ad populum. Narracją dominującą jest urąganie oraz oskarżanie reprezentantów wrogich sił socjalizmu i samego systemu; uwalnia ono powszechne niezadowolenie, frustrację i gniew. Staje się incydentalnym akordem rezonansu społecznego, być może - jak iskra rozniecająca ogień w beczce prochu - zaczynem ruchawki. Brzmiące refrenowo konstatacje obcych sobie ludzi osłabiają w jakimś sensie alienację jednostki, choćby tylko chwilowo, pobudzając ją do odrzucenia knebla cenzury, odzyskania własnej mowy, a tym samym osobistej godności. Publiczne - mimo obaw o represje - wygłoszenie swoich przekonań solidarnie wspierane głosem bliźniego staje się przedsmakiem wolności i potrzebą gromkiego zelżenia tych, którzy tę wolność ograniczają.

Szczególne znaczenie mają w obu tekstach wzmianki o res gestae. Ich wskrzesicielami są dwaj nestorzy, depozytariusze pamięci II Rzeczypospolitej. W Madame jest nim wspomniany „Sowiński”, on to solidaryzuje się ze spostponowanym pasażerem i wzburzony atakuje budzącego w nim pogardę jednego z bileterów:

- Wziąłbyś się lepiej, nygusie - grzmiał stentorowym tonem - do jakiej solidnej roboty, miast ludziom uprzykrzać życie. Najlepiej krowy pasać! Albo do chlewu z widłami! Myślisz, że my nie wiemy, o co tu się rozchodzi? Że premię masz od mandatów? [...] 
- Miałeś obsrane gacie, gdy ja walczyłem za Polskę! - Sowiński-w-okopach-Woli podniósł do góry laskę jak legendarną szpadę. ${ }^{13}$

Deprecjacja przeciwnika sugerująca jego chłopskie pochodzenie a tym samym umiejętności pozwalające mu na wykonywanie zawodów adekwatnych do urodzenia, tj. pasanie krów albo oporządzanie trzody chlewnej, ma charakter pars pro toto, czyli dyskredytację systemu socjalistycznego nie tylko zrównującego ze sobą ludzi różnych światów, ale dającego władzę prymitywnym i nieokrzesanym szumowinom. Odwołanie do walki za Polskę (zapewne podczas ostatniej wojny) z jednoczesnym doraźnie złowrogim, ale też symbolicznym gestem uniesienia ekwiwalentu oręża, stanowi casus oszukanego przez ideologię socjalistyczną Polaka-patrioty, pamiętającego lata walki i jej cel. Gorzkie, towarzyszące zarówno codzienności, jak i odświętności przekonanie "nie o taką Polskę walczyliśmy”, znajduje satysfakcjonujące ujście w ubliżaniu mandatariuszowi znienawidzonej państwowości. Stary warszawiak mnoży obelgi, nazywa adwersarza "nygusem" i „knurem” i co ważne, zwraca się do niego bezceremonialnie per ty, omijając wszelkie zwroty grzecznościowe, które naruszałyby zasadę decorum międzyludzkiej konwersacji, byłyby niestosowne wobec istoty tak niskiej jak bileter chłopskiego pochodzenia wywindowany siłą socjalistycznej równości na strażnika porządku publicznego.W degradacji tej uczestniczy również narrator, zadając sobie w myślach retoryczne pytanie: „Żeby taki paskudziarz, co wszystkie grzechy świata ma wypisane na twarzy, mógł żądać czegoś od innych. [...] To uwłacza godności i ogranicza wolność. Nie można się z tym pogodzić!"14. A jednak trudno było sprzeciwić się jawnie władzy ludowej w jej żądaniach podporządkowania się narzuconym zasadom, ich bojkot mógł zostać drogo okupiony. Spoiwem mikroświata efemerycznej społeczności, którą ukształtowała wspólna podróż, staje się kolektywna niezgoda na przejawy ingerencji coraz bardziej kompromitującego się państwa w codzienne funkcjonowanie obywateli, zamanifestowana głośnym zbiorowym protestem. Wulgaryzmy („obsrane gacie”, „możesz mi skoczyć... wiesz gdzie!",,,swołocz", ,bydło"15) i pogardliwy ton są uzewnętrznieniem nagromadzonych napięć, skutkiem rozgoryczenia, dezaprobaty i bezsilności tkwienia w absurdach peerelowskiej rzeczywistości.

13 Tamże.

14 Tamże, s. 227.

15 Tamże, s. 229. 
Znacznie bardziej wulgarne i ostrzejsze w retorycznych diatrybach są poznańskie „pogaduchy antysocjalistyczne”. Przez dwadzieścia lat, jakie dzieli te polskie rozmowy lokomocyjne, nagromadziło się już zbyt wiele narodowej żółci - marzec '68, rewolta grudniowa 1970, lipiec i sierpień '80, wreszcie stan wojenny; to dosyć, by przestać milczeć. Zarzewiem retorycznego agitato jest - jak już napisano - antybolszewicka konstatacja Olkiewicza wzmocniona reminiscencją o ojcu walczącym z „ruskimi” w roku 1920. Wyznanie to wyeksplikowane w stylistyce zrozumiałej dla ogółu przez jedną z jego interlokutorek: „A tego pana tatuś to tych zasrańców lał, jak nasi do Kijowa na ich plecach pojechali”16, uruchamia dalsze „antyruskie” komentarze, z których najwymowniejszym jest zaśpiew a capella „drobnego staruszka”: „Lance do boju, szable w dłoń, bolszewika goń, goń, goń. [...] A naszych poznańskich pułków to tak się bali, że boso przed nimi uciekali. Bo nasi ich rżnęli jak woły. Strach było patrzeć, bo po przejściu poznaniaków to nie było co zbierać"17. Wspomnienia zwycięskiej wojny z bolszewikami, a zwłaszcza słynnego 55 Poznańskiego Pułku Piechoty, nadają wypominkom lokalny charakter, wzmacniając solidarność kolektywną mocą dawnych zwycięstw. Ubolewanie nad obecnym stanem rzeczy: ,jakby nasi wtedy to całe robactwo wygnietli, to dzisiaj byśmy se żyli jak pączki w maśle, a nie jak te świnie w czerwonym chlewie"18 albo „Tych czerwonych to trzeba by wszystkich na Syberię wysłać, niech se tam porządki robią [...] Tak się ta czerwona hołota rządzi. A sami mają mordy spasione, bo wszystko dostają bez kartek"19, podsyca nienawiść do wspólnego wroga. Rychło agresja językowa obróci się przeciwko rodzimym reprezentantom „czerwonych”: reżimowej ekipie rządzącej („precz z komuną!”), a zwłaszcza generałowi Jaruzelskiemu („znajdzie się pała na dupę generała..."20), jako odpowiedzialnemu za nienawistny stan wojenny, strzelanie do rodaków, represje i internowania, kłamstwa polityczne i historyczne, cenzurę, upokarzającą reglamentację etc. Zwornikiem zaś emocji pozytywnych staje się „Solidarność".

Formułowanie obelg nie jest wyszukane; rozmówcy, by wyartykułować swoje niezadowolenie, posługują się tymi, które mają na podorędziu,

\footnotetext{
16 R. Ćwirlej Ręczna robota, s. 189.

17 Tamże.

18 Tamże.

19 Tamże.

20 Tamże, s. 190.
} 
przeważnie są one zależne od wykształcenia, kultury osobistej czy indywidualnej fantazji leksykotwórczej. W obu tekstach - wnioskując po socjolekcie - mamy raczej (wyjąwszy posługującego się intertekstualiami narratora Madame) do czynienia z ludźmi prostymi, o dość ograniczonym repertuarze środków językowych. Jak łatwo zauważyć, strategia deprecjacyjna w obu tekstach jest podobna i polega głównie na animalizacji, pojawiają się więc świnie (oraz chlew jako forma metonimii) i robactwo jako zwierzęta „brudne”, budzące wstręt; „bydło”, podobnie jak „swołocz” czy wyrażenie „mordy spasione” ma podkreślać nieokrzesanie wywołujące odrazę, a zwrot „rżnąć jak woły” ma na celu pognębienie ofiar jako istot bezmyślnych a przez to podległych i słabych.W pośpiesznym procesie konstruowania inwektyw - jak zazwyczaj, tak i tutaj - wykorzystuje się nieczyste części ciała (dupa) oraz wydzieliny ciała („obsrane gacie”,„zasrańcy”), ich abiektalność ma podkreślać konieczny dystans między ludźmi prawymi, a moralnie szkaradnymi, by się od nich nie ubrudzić.

\section{Coda}

Próby werbalnego unicestwienia przeciwnika w obu lokomocyjnych epizodach muszą jednak spełznąć na niczym, dalszemu ciągowi złowieszczego społecznego rozochocenia zapobiegną zjednoczone siły stróżów peerelowskiego prawa. Pasażerom autobusu linii 117 nie będzie dane opuszczenie pojazdu na przystanku przy - jakże znaczącym - Placu Przymierza. Kontrolerzy w porozumieniu z kierowcą autobusu porwą niesubordynowanych podróżnych "nikczemnym podstępem w odwecie za brak pokory"21, by zapewne rozprawić się z nimi z pomocą zawezwanej milicji. Jedynie narratorowi, dzięki fizycznej sprawności i zbiegowi okoliczności, udaje się zdezerterować w ostatniej chwili, a ucieczka ta, tak dramatyczna i tak literacko aluzyjna, wywołuje rozmaite pogłosy i kryptocytaty z przeczytanych lektur (Borowski, Różewicz, Andrzejewski), obejmując lokomocyjną przygodę maturzysty klamrą tradycji.

Dużo groźniej zakończy się zapewne antyradzieckie i antysocjalistyczne przymierze pasażerów poznańskiego tramwaju. Gdy w końcu przerażonemu swoją przypadkową popularnością Olkiewiczowi uda się opuścić miejsce kaźni, wysiąść nie bez perturbacji na najbliższym przystanku i uciec w popłochu jak najdalej od „napierających patriotów”, manifestujących w dalszym ciągu 
swoje „wywrotowe poglądy”, do interwencji przystąpi grupa zomowców. Jaki będzie przebieg tego spotkania, nietrudno przewidzieć.

\section{$* * *$}

Namysł nad specyfiką patriotycznych dysput lokomocyjnych z czasów socjalistycznego zniewolenia wiedzie do pytania o potrzebę uniwersalnych międzyludzkich więzi, które może spajać wspólny wróg. Dziś w Polsce bez kartek i kolejek tym wrogiem bywa - niezależnie od opcji politycznych - ekipa aktualnie rządząca, konkretni politycy, służba zdrowia, kler. To z ich powodu ceny zwyżkują, kolejki do lekarzy się wydłużają, a moralność staje się coraz bardziej relatywna. Dotyka to ludzkiej codzienności. Artykułuje się ją, tę powszedniość ułomną, jako rozczarowanie, niekiedy wzmocnione resentymentem z czasów młodości („komuno, wróć!”). Mniej ufny w porozumienie z Drugim (Innym) człowiek współczesny wydaje się jednak silniej wyalienowany niż kiedykolwiek, mniej - wskutek panteizmu i pluralizmu mediów, marketingu i konsumpcjonizmu - nastawiony na dialog, także wskutek zniechęcenia wszechobecną, zaraźliwą popkulturą. Może jest więc tak, jak pisze w Pikaresce Michał Olszewski, że dziś „zamiast konwersacji wybieramy milczenie, podróż w głąb neuroz, wykonywany z chirurgiczną precyzją rozbiór zaokiennych krajobrazów, ucieczkę w prasę bądź podręczniki, których lektura wyposaży nas w kolejne atuty na jakże wymagającym rynku pracy"22. 


\section{Abstract}

\section{Dorota Samborska-Kukuć}

UNIVERSITY OF ŁÓDŹ

"Anti-Socialist Chatter": Narrative Locomotive Polylogues

Samborska-Kukuć compares locomotive polylogues in two novels set in the Polish People's Republic - Antoni Libera's Madame and Ryszard Ćwirlej's Ręczna robota [HandMade]. Both writers portray social realities, such as general discontentment with the oppressive and repressive socialist state. The two novels are structurally analogous and share the same political message, representing the voice of the people in the postwar period of Soviet hegemony and its ideological derivatives (the Polish United Workers' Party, the Citizens'Militia and their Motorised Reserves, etc.). The means of transmission are polyphonic but complementary and homologous statements by travellers provoked by the artefact described. Despite the humour typical of popular forms, they can be read in terms of JózefTischner's personalist philosophy of the dialogue.

\section{Keywords}

polylogue, Antoni Libera, Ryszard Ćwirlej, Polish People's Republic, social realism 